\title{
The Influence of Using Students Worksheet, School Environment and Learning Motivation on Social Studies Learning Achievement
}

\author{
Zahroh Shoumi Indriyani*, Riril Mardiana Firdaus \\ Universitas PGRI Kanjuruhan Malang \\ Malang, Indonesia \\ *zahroh.shoumi@gmail.com, ririlmardiana@unikama.ac.id
}

\begin{abstract}
This article is intended to analyze the effect of using Student Worksheets (LKS) on Social Studies Learning Achievement, the influence of the School Environment on Social Studies Learning Achievement, the influence of Learning Motivation on Social Studies Learning Achievement, and the effect of using Student Worksheets (LKS), School Environment and Motivation. Learning towards Social Studies Learning Achievement. The research was conducted at SD Negeri 2 Sumberpucung with 83 students as subjects for grade IV, V and VI and the sample was taken using saturated samples. The approach used is quantitative with data analysis techniques using descriptive statistics. The results showed that: (1). There is a significant effect of using student worksheets on social studies learning achievement, that to get the maximum learning achievement, student worksheets are needed as a means of student learning. (2) there is a significant influence of the school environment on social studies learning achievement, to get high learning achievement, a good and comfortable school environment is needed. (3). There is a significant influence of learning motivation on social studies learning achievement, to achieve maximum learning achievement must be supported by high learning motivation as well. (4). There is an effect of using student worksheets, school environment, and learning motivation simultaneously on students' social studies learning achievement, in order to achieve maximum learning achievement student worksheets are needed, a good and comfortable school environment and high learning motivation in students.
\end{abstract}

Keywords-use of worksheets, school environment, learning motivation, learning achievement

\section{INTRODUCTION}

One important aspect in building the Indonesian nation is the existence of good quality human resources. Education has a role in preparing students to become qualified human beings. Education is a process of developing the human personality which includes knowledge, character, and skills. The educational process aims so that students can develop their potential so that they can become human beings who are noble, intelligent, have faith and piety and have useful skills for life in the future. National education starts from elementary school to middle school. Through elementary school, students get knowledge from the most basic as well as character education as a provision to go to a higher education level.

Learning is a process to achieve what you aspire to, improving attitudes and actions. The results of learning are indicated by changes or improvements in behavior, for example being able to know and understand something that was previously unknown. The teaching and learning process involves teachers and students. The teacher is in charge of teaching and educating students. Teaching means imparting knowledge to students at school. The interaction between teachers and students in learning and teaching activities is in the form of educational interactions, which is not only the delivery of messages in the form of knowledge, but also the inculcation of attitudes and values in students who are learning [1].

The teaching process requires one of the means, namely teaching materials. This is necessary to improve the quality of learning. Improvement of facilities and infrastructure that support the learning process is a development that must be carried out in an effort to improve the quality of learning [2]. One of the teaching materials that can be used is Student Worksheets (LKS). Student worksheets can be made so that it is easier for students to learn and explore the subject matter, so that they can be a guide in learning. Student worksheets also help the teacher to arrange a series of teaching. In the LKS, the teacher can develop the potential and skills that students need to have.

Teachers have the responsibility to maintain the classroom environment, so that students can feel happy and comfortable in learning, so they can focus more on receiving the lessons delivered by the teacher. A conducive atmosphere is needed in the learning process because in learning subject matter concentration is needed to solve practice questions. The school environment also plays an important role in the success of students to achieve the expected achievements. A good family and school environment, especially in the learning process, is something that can support success in increasing student learning achievement [3]. 
Regarding learning achievement, student motivation is needed. Motivation is the most important factor in teaching and learning activities. Motivation is defined as an impetus that arises from within a person to do an action or attitude. In another sense, motivation to learn is a strength or energy that can spur students to carry out learning activities. It can be believed that learning achievement will increase if students have high learning motivation. Basically students can be motivated to do an activity for themselves, in this case the enthusiasm for learning, because they want to achieve goals, for example new knowledge, want to get awards or praise and good grades.

SD Negeri 2 Sumberpucung is one of the educational institutions in Malang Regency that is committed to quality so that it can become a superior school. The school's vision for achievement is based on science and technology and IMTAK and has an environmental perspective. Various ways are done so that students can achieve such as additional lessons so that students can better understand and understand learning materials.

The indicator of achievement is the value issued by the teacher which is obtained from the evaluation results. This value can be high, medium or low, so it can be said that an achievement can be good or bad. Students are said to be successful if they reach the minimum completeness criteria (KKM) determined by the school. However, the problem that becomes an obstacle in the field of education in general and in the context of this research SD Negeri 2 Sumberpucung is the low learning achievement of some students, which is known from the results of tests that have not reached the KKM criteria that have been determined by the school. Based on this, the researcher wants to reexamine student learning motivation by adding variables to the use of Student Worksheets (LKS) and the school environment. The school environment and learning motivation are interrelated, as well as the use of student worksheets to support enthusiasm for learning in the hope that student achievement can increase.

\section{RESEARCH Methods}

This study uses a quantitative approach. The purpose of quantitative research is to test existing theories, construct a fact, show the relationship between independent and dependent variables, provide statistical data, and predict the results. Research that uses a quantitative approach must be structured, standardized format and pre-designed [4].

This research uses descriptive research. This type of descriptive research consists of several types, namely: pure descriptive research (survey), correlation, comparison, and traceability research. And in this study using descriptive correlation research. Correlation research (correlational research) is research conducted to determine the level of the relationship between two or more variables, and not to make changes, additions or manipulation of existing data [5].
The method used in this research is multiple linear regression method. Multiple linear regression is a statistical method used to research the effect between the independent variable (independent) and the dependent variable (dependent). Multiple linear regression can contain two or more independent variables. Regression analysis is generally used to analyze the magnitude of the influence between four variables, if there is a significant effect among them. The population taken in this study were all students of class IV, class V, and class VI at SD Negeri 2 Sumberpucung, totaling 83 people, and the sample used was saturated sample. According to Sugiyono, saturated sample is a sampling technique if all members of the population are used as the sample [6].

The independent variables (independent) in this study are the use of worksheets, school environment and learning motivation. Meanwhile, the dependent variable is Learning Achievement.

\section{RESULTS AND DISCUSSION}

The results of multiple regression analysis using SPSS 22 program assistance can be seen in the Table 1 .

TABLE I. MULTIPLE LINEAR REGRESSION TEST RESUlT COEFFICIENTS

\begin{tabular}{|c|c|c|c|c|c|}
\hline Model & \multicolumn{2}{|c|}{$\begin{array}{c}\text { Unstandardized } \\
\text { Coefficients }\end{array}$} & $\begin{array}{c}\text { Standardized } \\
\text { Coefficients }\end{array}$ & \multirow{2}{*}{ t } & \multirow{2}{*}{ Sig } \\
\hline & $\boldsymbol{B}$ & Std. Error & Beta & & \\
\hline (Constant) &, 912 & 7,048 & &, 129 &, 037 \\
\hline Total_X1 &, 431 &, 102 &, 411 & 4,223 &, 000 \\
\hline Total_X2 &, 339 &, 097 &, 335 & 3,477 &, 001 \\
\hline Total_X3 &, 219 &, 098 &, 216 & 2,229 &, 029 \\
\hline
\end{tabular}

a. Dependent Variable: Y

Based on the table 1 above, it can be seen that the constant is 0.912 and the coefficient for the LKS use variable (X1) is 0.431 and the school environment variable coefficient (X2) is 0.339 and the learning motivation variable coefficient is 0.219 so that the regression model equation is:

$$
\mathrm{Y}=0.912+0.431 \mathrm{X} 1+0.339 \mathrm{X} 2+0.219 \mathrm{X} 3
$$

The regression model equation can be interpreted as follows:

- Constant $=0.912$ states that if the variable use of worksheets (X1), School Environment (X2) and Learning Motivation (X3) the value is 0 , then the Learning Achievement variable (Y) is 0.912 .

- The coefficient of using student worksheets $(\mathrm{X} 1)=$ 0.431 states that if the variable using student worksheets has increased by 1 point and other variables are considered constant, the learning achievement variable (Y) has increased by 0.431 .

- The School Environment Coefficient $(X 2)=0.339$ states that if the School Environment variable has increased by 1 point and other variables are considered 
constant, the Learning Achievement variable (Y) has increased by 0.339 .

- The Learning Motivation Coefficient (X3) = 0.219 states that if the Learning Motivation variable has increased by 1 point and other variables are considered constant, the Learning Achievement variable (Y) has increased by 0.219 .

Based on these results, the following is a discussion of the results of hypothesis testing. The result of the multiple $\mathrm{R}$ coefficient significance test which shows the magnitude of the influence between the student worksheet use variable (LKS), school environment and learning motivation as the independent variable and learning achievement as the dependent variable simultaneously shows a significant influence. This is indicated by the magnitude of the F statistical value of 11,068 compared to the F-table of only 2.72. Thus the results of the significance test indicate that the theory and findings used as the basis of this research are relevant.

The results of the t-test used to determine the effect of each variable partially show that there is an effect of the use of student worksheets on learning achievement with a t-statistic value of 4,223 this value is greater than the t-table (4.223> 1.990). While the influence of the school environment on learning achievement is indicated by a statistical t-value of 3.477 , this value is greater than the table (3.477> 1.990), this result shows that the school environment variable affects learning achievement. The effect of learning motivation on learning achievement is indicated by the t-statistic value of 2.229 , this value is greater than the t-table $(2.229>1.990)$, this result shows that the learning motivation variable has an effect on learning achievement. Furthermore, the above results are discussed as follows.

\section{A. The Effect of Using LKS on Learning Achievement}

The results of the study prove that there is a significant effect of using student worksheets on the learning achievement of grade IV, class V, and class VI students at SD Negeri 2 Sumberpucung in the 2019/2020 academic year. Based on the SPSS results, the p-value for the variable using LKS (X1) was obtained in the Sig. is 0.000 less than alpha 0.05 or the t-count value is greater than the t-table at the $5 \%$ significance level, namely 4.223>1.990, which means that whether or not the use of LKS has an effect on Student Achievement in Class IV, Class V, and Class VI in Elementary School 2 Sumberpucung for the 2019/2020 academic year, the better the use of worksheets, the higher the learning achievement of grade IV, class V, and VI grade students at Sumberpucung 2 Elementary School for the 2019/2020 school year and vice versa if the use of student worksheets is getting lower, then the learning achievement of grade IV students, Class V, and Class VI at SD Negeri 2 Sumberpucung in the 2019/2020 academic year will also be low.

Student worksheets can be used as a guide for students to carry out learning activities independently and can be used to develop knowledge. In student worksheets (LKS), there is a social studies subject matter where students will get an explanation of the material, assignments, and practice questions related to social studies lessons. For this reason, the use of student worksheets is indispensable in social studies content to improve student achievement.

\section{B. The Influence of the School Environment on Learning Achievement}

The results of the study prove that there is a significant effect of the School Environment on Student Achievement of Class IV, Class V, and Class VI at Sumberpucung 2 Elementary School in the 2019/2020 academic year. Based on the SPSS results, the p-value for the School Environment variable (X2) was obtained in the Sig. is 0.001 less than alpha 0.05 or the $\mathrm{t}$-count value is greater than the $\mathrm{t}$-table at the $5 \%$ significance level, namely 3.477> 1.990, which means that the high and low level of the School Environment affects the Learning Achievement of Class IV, Class V, and VI Class Students in SD Negeri 2 Sumberpucung years 2019/2020, the higher the School Environment, the higher the Learning Achievement of Class IV, Class V, and Class VI Students in SD Negeri 2 Sumberpucung School for the 2019/2020 academic year and vice versa if the School Environment is getting lower, the learning achievement of grade IV, grade V, and class VI at SD Negeri 2 Sumberpucung in the 2019/2020 academic year will also be low.

The school environment is conducive, comfortable and pleasant and supported by all facilities can support students to concentrate in learning, so that the expected achievements can be realized. This is the task of teachers and school officials to achieve this.

\section{Effect of Learning Motivation on Learning Achievement}

The results of the study prove that there is a significant effect of learning motivation on the learning achievement of grade IV, class V, and class VI students at SD Negeri 2 Sumberpucung in the 2019/2020 academic year. Based on the SPSS results, the p-value for the Learning Motivation variable (X3) is obtained in the Sig. is 0.029 less than alpha 0.05 or the $\mathrm{t}$-count value is greater than the $\mathrm{t}$-table at the $5 \%$ significance level, namely 2.229>1.990, which means that good or bad learning motivation has an effect on the learning achievement of students in grade IV, class V, and class VI in Elementary School 2 Sumberpucung years. teaching 2019/2020, the better the Learning Motivation, the better the Learning Achievement of Class IV, Class V, and VI Class Students in SD Negeri 2 Sumberpucung in the 2019/2020 academic years and vice versa if the Learning Motivation gets worse, then the Learning Achievement of Class IV, Class V and Class VI Students in Elementary School 2 Sumberpucung academic year 2019/2020 will also be bad too.

Motivation to learn is needed in students so that they can receive the learning material delivered by the teacher, so that it can support learning achievement. Students who have the motivation to study social studies material, then these students will be able to follow the lesson well so that they can work on 
questions about social studies material. The learning motivation of students in grades IV, V and VI SD Negeri 2 Sumberpucung affects social studies learning achievement, because with the desire or enthusiasm to study social studies material, the value will increase.

\section{The Influence of Using LKS, School Environment and Learning Motivation on Learning Achievement}

The results of the above research prove that there is a significant effect of using student worksheets, school environment, and learning motivation on student achievement in grade IV, class $\mathrm{V}$, and class VI at SD Negeri 2 Sumberpucung in the 2019/2020 school year. Based on the SPSS results, the value of Adjusted R Square was 0.296 or $29.6 \%$. This shows that the variable use of student worksheets, school environment and learning motivation affects Learning Achievement variable by $29.6 \%$, while the remaining $70.4 \%$ is influenced by other factors not examined in this study.

The role of the use of student worksheets, the school environment and learning motivation are very important in the learning process. A good and conducive school environment is needed to achieve learning goals, so it requires the role of school apparatus, especially teachers and school principals, as well as families and communities. Students are also expected to continue to grow their learning motivation with the support of teachers and families so that learning achievement is achieved as expected.

\section{CONCLUSION}

Based on the results of the data analysis above, it can be concluded that there is a significant effect of using student worksheets on social studies learning achievement. This means that to obtain maximum learning achievement, Student Worksheets are needed as a means of student learning. Then there is a significant influence of the school environment on social studies learning achievement. This shows that to get high learning achievement, a good and comfortable school environment is needed. Then there is a significant effect of learning motivation on social studies learning achievement. This means that to achieve maximum learning achievement must be supported by high learning motivation as well. Then there is the effect of using worksheets, the school environment, and learning motivation simultaneously on student social studies achievement. This shows that in order to achieve maximum learning achievement, student worksheets are needed, a good and comfortable school environment and high learning motivation in students. From the results of this research, it is hoped that it can be used as a material for consideration of learning in schools, the school always creates a good, comfortable and conducive environment to increase student motivation so that they can achieve the expected achievements.

\section{REFERENCES}

[1] N. Nurhaidah and M.I. Musa, "Pengembangan kompetensi guru terhadap pelaksanaan tugas dalam mewujudkan tenaga guru yang profesional,” Jurnal Pesona Dasar, vol. 2, pp. 8-27, 2016.

[2] A. Fajriyatin, "Analisis buku siswa matematika K-13 kelas IX bab sistem persamaan linear dua variabel berdasarkan konten pada kriteria bell," Seminar nasional matematika dan pendidikan matematika, Jurusan Pendidikan Matematika FMIPA UNY, Yogyakarta, 2015.

[3] M. Muslih, "Pengaruh lingkungan keluarga dan lingkungan sekolah terhadap prestasi belajar siswa kelas 6 SDN Limbangan," Journal Ilmiah Indonesia, vol. 1, pp. 121-127, 2016

[4] A. Tanzeh, Metodologi penelitian praktis. Yogyakarta: Teras, 2011.

[5] S. Arikunto, Prosedur penelitian: Suatu pendekatan praktik. Jakarta: PT. Rineka Cipta, 2010.

[6] S. Sugiyono, Metode penelitian kuantitatif kualitatif. Bandung: Alfabeta, 2013. 